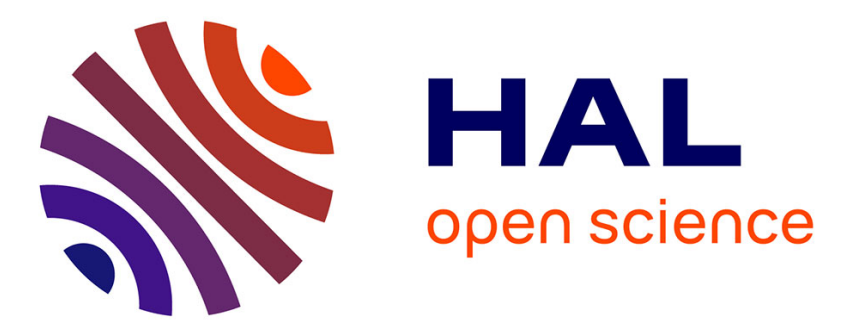

\title{
Effect of grass cover on water and pesticide transport through undisturbed soil columns, comparison with field study (Morcille watershed, Beaujolais)
}

S. Dousset, M. Thevenot, D. Schrack, V. Gouy, N. Carluer

\section{- To cite this version:}

S. Dousset, M. Thevenot, D. Schrack, V. Gouy, N. Carluer. Effect of grass cover on water and pesticide transport through undisturbed soil columns, comparison with field study (Morcille watershed, Beaujolais). Environmental Pollution, 2010, 158 (158), p. 2446 - p. 2453. 10.1016/j.envpol.2010.03.028 . hal-00584905

\section{HAL Id: hal-00584905 \\ https://hal.science/hal-00584905}

Submitted on 11 Apr 2011

HAL is a multi-disciplinary open access archive for the deposit and dissemination of scientific research documents, whether they are published or not. The documents may come from teaching and research institutions in France or abroad, or from public or private research centers.
L'archive ouverte pluridisciplinaire HAL, est destinée au dépôt et à la diffusion de documents scientifiques de niveau recherche, publiés ou non, émanant des établissements d'enseignement et de recherche français ou étrangers, des laboratoires publics ou privés. 
Author-produced version of the article published in Environmental Pollution, $\mathrm{n}^{\circ}$ 158, p. 2446-2453. The original publication is available at http://www.sciencedirect.com/ doi: 10.1016/j.envpol.2010.03.028

\section{Effect of grass cover on water and pesticides transport through undisturbed soil} columns, comparison with field study (Morcille watershed, Beaujolais)

(3)

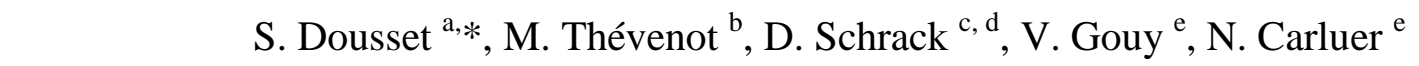
(1)

${ }^{a}$ Nancy-Université, CNRS, LIMOS, BP 70239, 54506 Vandoeuvre-les-Nancy, France.

${ }^{\mathrm{b}}$ Université de Lille 1, CNRS, Géosystèmes, 59655 Villeneuve d'Ascq, France.

${ }^{\mathrm{c}}$ INRA-SAD ASTER, 88500 Mirecourt.

${ }^{\mathrm{d}}$ AFSSA, Laboratoire d'Etudes et de Recherches en Hydrologie, 54000 Nancy, France.

${ }^{\mathrm{e}}$ UR Milieux Aquatiques, Ecologie et Pollution, Cemagref, 69336 Lyon Cedex, France.

Capsule: Grass-covered soils reduce the amount of pesticide leaching, due mainly to their higher organic matter contents, thereby reducing the risk of groundwater contamination.

\section{ABSTRACT}

The purpose of this work is to assess the effectiveness of two grass covers (buffer zone and grass-covered inter-row), to reduce pesticide leaching, and subsequently to preserve groundwater quality. Lower amounts of pesticides leached through grass-cover soil columns $(2.7-24.3 \%$ of the initial amount) than the bare soil column $(8.0-55.1 \%)$, in correspondence with their sorption coefficients. Diuron was recovered in higher amounts in leachates $(8.9-32.2 \%)$ than tebuconazole $(2.7-12.9 \%)$, in agreement with their sorption coefficients. However, despite having a sorption coefficient similar to that of diuron, more procymidone was recovered in the leachates $(10.2-55.1 \%)$, probably due to its facilitated transport by dissolved organic matter. Thus even in this very permeable soil, higher organic matter contents associated with grass-cover reduce the amount of pesticide leaching and limit the risk of groundwater 
1 contamination by the pesticides. The results of diuron and tebuconazole transfer through

2 undisturbed buffer zone soil columns are in agreement with field observations on the buffer 3 zone.

4

5

$6 \quad *$ Corresponding author. Tel.: +33 (0)3 836842 93; fax: +33 (0)3 83684284 .

$7 \quad$ E-mail adress: sylvie.dousset@limos.uhp-nancy.fr

8

9 Keywords: Buffer zone; Grass cover; Vineyard soil; Leaching; Pesticide; Commercial 10 formulation

11

12 


\section{1. Introduction}

3

As a result of numerous sources of pollution, including the use of agricultural pesticides, drinking waters resources are becoming increasingly scarce and a crucial issue for developed countries. It is critical that solutions are proposed to better protect water quality, in particular that of surface waters, which are generally the most contaminated and also the most sensitive to contamination (IFEN, 2006). Viticulture is an important agricultural sector in France, and a great consumer of pesticides to control disease, insect damage and weed competition in the vineyards. Consequently, many recent studies have reported the presence of pesticide residues in surface- or ground waters near several vineyards at concentrations higher than the European regulatory limit of $0.1 \mu \mathrm{g} \mathrm{L}^{-1}$ for drinking water (ECC, 1998), and the European Quality Standards defined for some pesticides in the European Water Framework Directive as, for example, in France (Lennartz et al., 1997; Louchart et al., 2004) and in Spain (Bermudez-Couso et al. 2007). Consequently, agricultural institutions advise wine producers to use alternative practices to chemical weeding and to reduce pesticide transfer by adopting management practices such as grass covered inter-rows or buffer zones.

Numerous studies have shown that the grass cover reduces erosion and runoff due to sediment deposition and increases water infiltration within the vegetated zone (Dillaha et al. 1989; VanDijk et al., 1996). More recent works have been concerned with the use of these buffer zones to limit surface water contamination by pesticides. A number of authors have reported that the amount of pesticide in the runoff from vegetated buffer zones is lower than the amount entering the zone (Patty et al., 1997; Schmitt et al., 1999; Watanabe et al., 2001). The effectiveness of the vegetated buffer zones at reducing the amounts of pesticide in the runoff may be explained by the processes of retention and/or infiltration within the zone 
1 (Kloppel et al., 1997; Mersie et al., 1999; Seybold et al., 2001; Delphin and Chapot, 2001;

2 Souiller et al., 2002; Benoit et al., 2003; Mersie et al., 2003). Lacas et al., (2005) and Krutz et

3 al (2005) reviewed the various parameters affecting pesticide infiltration and/or retention in

4 vegetative filter strips. The respective proportion of the two processes in the reduction of

5 pesticide runoff depends on the affinity of the molecules for the soil (sorption) (Arora et al.,

6 2003; Boyd et al., 2003). For example, a reduction of relatively water soluble herbicides, such

7 as atrazine and metolachlor, in the runoff from a vegetated zone could be explained by increased infiltration; whereas, reduction in chlopyrifos runoff would be due to sorption onto the sediments retained by the buffer zone vegetation (Arora et al., 2003). Similar conclusions were reached by Boyd et al. (2003) who showed that chlorpyrifos was retained on sediments deposited in vegetated buffer zones; whereas, atrazine and acetochlor infiltrated the soil and were detected in the drains.

However, reducing the quantities of pesticides found in surface waters by promoting their infiltration in buffer strips may threaten shallow water tables or even groundwater with pesticide contamination. On the one hand, various studies have shown that the sorption and degradation of pesticides is higher in vegetated zones than in cultivated soils (Benoit et al., 1999; Madrigal et al., 2002; Krutz et al., 2003; Krutz et al., 2004) or fallow soils (Staddon et al., 2001). On the other hand, these were laboratory batch studies somewhat removed from the reality of field conditions. It is likely that the more infiltration rates through a vegetated soil increase, the less physico-chemical equilibrium is reached. In particular the degree of nonequilibrium of sorption increases with water flow as showed by Pot et al. (2005) and Vincent et al. (2007); potential sorption and degradation of the compounds would decrease relative to the results of the batch studies in which steady-state conditions are attained. Nevertheless, very few studies have been conducted on the quantities of pesticides leached from vegetated soils and the results of these studies are contradictory. In some cases, the use of grass covers 
1 on soil reduces the amounts of pesticides leached compared with the amounts leached from

2 cultivated or fallow soils (Liaghat and Prasher, 1996 ; Benoit et al., 2000), in other cases,

3 there was no difference (Belden and Coats, 2004). Thus, our work contributes to a better

4 understanding of pesticide leaching through grass-covered soil, in particular structured soils

5 sensitive to leaching (loamy sand) that are representative of a widespread vineyard areas in

6 France.

The Cemagref of Lyon established an experimental site in St Joseph (Beaujolais, France) in 2004, in order to assess the efficiency of vegetated buffer zones to reduce pesticide runoff and the subsequent pesticide infiltration through the buffer zone (Boivin et al., 2007).

It consisted of an experimental plot laid out on an old meadow vegetated buffer zone $(6 \times 4.2$ $\mathrm{m}^{2}$ ) interposed between the vineyard uphill and the Morcille stream downhill. An homogeneous distribution of water inflow was ensure at the upper end of the buffer zone. Soil water content was monitored during the water inflows using tensiometers and humidimeters located at different position in the experimental plot. In addition, lysimeters implemented at different locations were designed for collecting soil water at $50 \mathrm{~cm}$ depth when runoffs were simulated. They clearly demonstrated a global reduction in pesticide concentrations (diuron and tebuconazole) leached to a $50 \mathrm{~cm}$ soil depth relative to the initial concentration of the incoming runoff. Their attempts to quantify the reduction, however, were hampered by the difficulty in obtaining reliable mass balances in the field from pesticide concentration measured in lysimeters which collected a limited fraction of the total infiltration through the buffer zone ( $4 \%$ of the total buffer surface). Moreover, no field data on pesticide leaching through neither the cultivated bare soil nor the inter-row grassed soil were available for comparison in this site. Thus, the objectives of this work were (i) to implement an experiment allowing the comparison of pesticide leaching in the buffer zone soil with a bare cultivated 
1 experiment; (ii) to better assess the role of two grass cover modalities (buffer zone and grass

2 covered inter rows) on water infiltration, and leaching or sorption of one herbicide (diuron)

3 and two fungicides (tebuconazole and procymidone), through a Beaujolais vineyard soil

4 during runoff events; and (iii) to compare the possible release of pesticides from soils after

5 subsequent runoff events. The pesticide leaching was studied using undisturbed soil columns

$6\left(\begin{array}{llll}15 & \mathrm{x} & 20 & \mathrm{~cm}\end{array}\right)$ in laboratory and outdoor conditions. These two experiments were

7 complementary: monitoring some metabolites in the leachates under laboratory conditions, and the additional grass-cover modality under outdoor conditions (inter-row vineyard). The loamy sand soil was sampled in a chemically-weeded plot, in an adjacent buffer zone and in a grass-covered inter-row plot. Several runoff events, with and without pesticides were 11 simulated, and pesticide concentrations were monitored in the column leachates. The results of our work were compared to those obtained at the experimental site in St Joseph by Boivin et al. (2007). This increased our understanding of the fate of pesticides in grass covered soils compared to bare soil, and showed their potential reduce the pesticide leaching through soil thus preserving groundwater quality.

\section{Material and methods}

\subsection{Chemicals} dimethylurea) and two of its metabolites, DCPMU (3-3,4-dichlorophenyl-N,N-methylurea) and DCPU (3-3,4-dichlorophenylurea), tebuconazole ((RS)-1-p-chlorophenyl-4,4-dimethyl-3$(1 \mathrm{H}-1,2,4-$ triazol-1-ylmethyl $)=$ pentan-3-ol $)$, and procymidone $(\mathrm{N}-(3,5$-dichlorophenyl)-1.2- 
1 Grande, France) with $>99 \%$ certified purity. The main physico-chemical properties of the

2 pesticides are listed in Table 1. Commercial pesticide formulations were used: Canyon

3 (diuron $71 \mathrm{~g} \mathrm{~L}^{-1}$ ), Folicur EW (tebuconazole $250 \mathrm{~g} \mathrm{~L}^{-1}$ ) and Sumisclex (procymidone $500 \mathrm{~g} \mathrm{~L}^{-}$

$4{ }^{1}$ ) in order to obtain more realistic results.

\subsection{Soil sampling and column set-up}

The experimental site monitored by Cemagref of Lyon (69, France) is located in the

Beaujolais region near St Joseph (Rhône, France). It consists of an experimental plot (25.2

$\mathrm{m}^{2}$ ) on a $25 \%$ slope laid out on a vegetated buffer zone, located between a chemically-treated

hillside vineyard and the Morcille stream. For the field experiment, soil water content was monitored through the buffer strip using humidimeters and tensiometers, and pesticide concentrations and fluxes were measured in soil water collected using lysimeters (Jordan, 1968; Boivin et al., 2007; ). These lysimeters correspond to water percolation sampler consisting of two similar and joint horizontal stainless steel plates $\left(0.25 \times 0.25 \mathrm{~cm}^{2}\right)$ making the gravimetric soil water flow converging into underlying glass bottles by means of a Teflon capillary tube. The plates were placed at $50 \mathrm{~cm}$ depth under the soil surface taking care not to disturb the underlying soil owing to a lateral slice in the ground which was filled after the installation. A set of two other capillary tubes permitted to set the system at the atmospheric pressure and to transfer the percolated water from the buried bottles to the surface for measurements (water volumes and solute concentrations). In the field experiment, pesticide leaching was monitored only in the buffer zone; then the chemically-treated soil and a complementary site in the same vineyard consisted of a grass-covered inter-row plot allowed to collect soil columns. No runoff occurred on this buffer strips that means that all the entering water flow infiltrated into the soil. The soil is a sandy loam (arenic cambisol, FAO, 
1 1998). Column extraction of the soil occurred in March 2006 (outdoor conditions) and in

2 March 2007 (laboratory conditions) before pesticide treatment of the fields, and was

3 facilitated by the use of a shovel to carefully excavate the surrounding soil. Final carving of

4 the soil was carefully performed by hand resulting in $15-\mathrm{cm}$ diameter cylinders of structured

5 soil. A 25-cm long polyvinyl chloride (PVC) pipe with an internal diameter of $20 \mathrm{~cm}$ was

6 placed around each soil cylinder. The space between the pipe and soil was filled with

7 expandable foam to prevent water from moving preferentially down the side of the pipe rather

8 than through the soil. The minimal expansion foam was allowed to cure overnight. The

9 columns were then removed from the field by digging under the PVC pipe, and placing nylon mesh (105 $\mu \mathrm{m}$ openings) at the bottom of each column base to retain the soil. Preliminary experiments showed that no sorption was measured on the minimal expansion foam either on the nylon mesh. Six columns were brought back to the laboratory ( 3 columns from the bare soil, $\mathrm{B}_{\mathrm{L} 1}, \mathrm{~B}_{\mathrm{L} 2}$ and $\mathrm{B}_{\mathrm{L} 3}$ and, three from the buffer zone, $\mathrm{BZ}_{\mathrm{L} 1}, \mathrm{BZ}_{\mathrm{L} 2}$ and $\mathrm{BZ}_{\mathrm{L} 3}$ ). In addition, ten undisturbed soil columns were brought to the experimental site at INRA-Dijon in march 2006 for installation in an outdoor, in-ground lysimeter collection system (4 columns from the bare soil, $\mathrm{B}_{\mathrm{O} 1}, \mathrm{~B}_{\mathrm{O} 2}, \mathrm{~B}_{\mathrm{O} 3}$ and $\mathrm{B}_{\mathrm{O} 4}$, three from the buffer zone, $\mathrm{BZ}_{\mathrm{O} 1}, \mathrm{BZ}_{\mathrm{O} 2}$ and $\mathrm{BZ}_{\mathrm{O} 3}$ and three from the grassed-cover vineyard, $\mathrm{GC}_{\mathrm{O} 1}, \mathrm{GC}_{\mathrm{O} 2}$ and $\mathrm{GC}_{\mathrm{O} 3}$ ). This device previously used by Landry et al. (2006), consisted of a perforated PVC support connecting the columns to funnels, with PFTE-lined collection tubing leading to high-density polyethylene bottles in an underground pit. The volume around the columns was backfilled with sand to simulate field conditions. The outdoor lysimeters allowed studying the impact of the outdoor environmental conditions (temperature, rainfall, and solar radiation) on the degradation of pesticides between the different runoff inflows. 


\subsection{Water inflows and experimental set-up}

(1)

Same artificial inflows (simulating vineyard runoff events) were replicated at three different times $\left(\mathrm{T}_{0}, \mathrm{~T}_{14}\right.$ and $\mathrm{T}_{28}$ days, respectively) on the soil surface for laboratory and outdoor columns. The first water inflow $\left(\mathrm{T}_{0}\right)$ contained a homogeneous mixture of $5 \mathrm{mg} \mathrm{L}{ }^{-1}$ bromide and $100 \mu \mathrm{g} \mathrm{L}^{-1}$ diuron, procymidone or tebuconazole, simulating contaminated runoff after a rainfall event. Bromide was added as a tracer of water transfer. Input concentrations were selected based on previous work on contaminated runoff from vineyard (Louchart et al., 2001) and local references (Lacas, 2005). A 3.6 L volume of solution was applied onto the surface of each column $\left(176.6 \mathrm{~cm}^{2}\right)$, which is equivalent to the $4800 \mathrm{~L}$ water volume applied to the experimental vegetated buffer zone $\left(25.2 \mathrm{~m}^{2}\right)$ in the field experiment monitored by Boivin et al (2007). This simulated runoff corresponds to a $<2$-yr rain event frequency (Lacas, 2005). The bromide-pesticide solution was applied onto the top of each laboratory or outdoor soil column at a constant flow rate of $10.2 \mathrm{~cm} \mathrm{~h}^{-1}$ using a peristaltic pump. This rate is lower than that used in the study by Boivin et al. $2007\left(28 \mathrm{~cm} \mathrm{~h}^{-1}\right)$, but it is within a realistic range; indeed, Lacas (2005) reported a slightly higher field saturation hydraulic conductivity of $12.5 \mathrm{~cm} \mathrm{~h}^{-1}$ at $15 \mathrm{~cm}$ depth. Two additional water inflows, consisting only of 3.6 L of water, were applied to the columns fourteen $\left(\mathrm{T}_{14}\right)$ and twenty eight days $\left(\mathrm{T}_{28}\right)$ after the pesticide application in order to assess potential pesticide release from the soil. Each inflow lasted 3 hours in average, except for the grass-covered inter-row soil (26h). During the laboratory experiment, the soil water saturation was $55 \% \pm 4 \%$ for the bare soil and, $64 \% \pm 6 \%$ for the buffer zone soil. The laboratory soil columns were maintained at $20^{\circ} \mathrm{C} \pm$ $2^{\circ} \mathrm{C}$, whereas the mean outdoor temperature was $12^{\circ} \mathrm{C}$ during the monitored period from the 27 of March to 23 of April 2007; rainfall was scarce, less than $15 \mathrm{~mm}$ (<5\% of the runoff water). 


\subsection{Leachate collection and analyses}

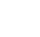

Laboratory and outdoor column effluent was collected at 6-min intervals in 250-mL glass bottles. Leachate volumes were determined gravimetrically. Each leachate sample from the first water inflow $\left(\mathrm{T}_{0}\right)$ was kept for analysis. When collecting effluent from the second $\left(\mathrm{T}_{14}\right)$ and third $\left(\mathrm{T}_{28}\right)$ water inflow events, three consecutive samples were mixed; so that, column effluent was essentially collected at 18 -min intervals. Pesticide residues contained in the leachates were concentrated by solid-phase extraction with a LC-18 bonded silica cartridge (3 mL, Supelclean, Supelco) for water-sample volumes $<100 \mathrm{~mL}$ or with an LC-18 bonded silica cartridge (12 mL, Supelclean, Supelco) for water-sample volumes $>100 \mathrm{~mL}$. The cartridges were pre-conditioned with similar volumes of acetonitrile then distilled water, $2 \times 1 \mathrm{~mL}$ for the $3 \mathrm{~mL}$ cartridge, and $2 \times 2.5 \mathrm{~mL}$ for the $12 \mathrm{~mL}$ cartridge. The pesticide residues adsorbed by the $12 \mathrm{~mL}$ LC-18 cartridges were eluted using $2 \times 2 \mathrm{~mL}$ of acetonitrile ( $2 \times 1 \mathrm{~mL}$ for the $3 \mathrm{~mL}$ cartridge), and evaporated to dryness in a rotary evaporator at $30^{\circ} \mathrm{C}$. The residues were then dissolved in $5 \mathrm{~mL}$ of methanol $(2 \mathrm{~mL}$ for the $3 \mathrm{~mL}$ cartridge $)$ and stored at $-18^{\circ} \mathrm{C}$ prior to analysis. Respective mean recovery rates for $3 \mathrm{~mL}$ and $12 \mathrm{~mL}$ cartridges were $99.3 \%$ and $95.8 \%$ for diuron, $98.3 \%$ and $95.1 \%$ for DCPMU, $97.5 \%$ and $88.8 \%$ for DCPU, and $94.6 \%$ and $82.6 \%$ for procymidone and $55.7 \%$ and $55.6 \%$ for tebuconazole. All sample concentrations were corrected based on these recovery values. Samples were analyzed using a Waters HPLC equipped with a Diode Array Detector and a 25 cm x 4.6 mm C18-column packed with Kromasil $5 \mu \mathrm{m}$ for tebuconazole, procymidone, diuron and its two metabolites DCPMU and DCPU, and a $15 \mathrm{~cm}$ x $4.6 \mathrm{~mm}$ Waters IC Pack Anion $\mathrm{HC}$ for $\mathrm{Br}^{-}$. The mobile phase was acetonitrile-water at 70/30 v/v for the pesticides and a sodium borate-gluconate eluent with $12 \%$ of acetonitrile for bromide. The flow rate of the mobile phase was $0.8 \mathrm{~mL} \mathrm{~min}^{-1}$ for the pesticide analyses, and $1.8 \mathrm{~mL} \mathrm{~min}^{-1}$ for bromide. UV 
1 detection was performed at $249 \mathrm{~nm}$ for diuron, DCPMU and DCPU, $220 \mathrm{~nm}$ for tebuconazole

2 and $203 \mathrm{~nm}$ for procymidone and $200 \mathrm{~nm}$ for bromide. Minimum detectable levels of residues

3 extracted with SPE cartridges respectively were: $1 \mu \mathrm{g} \mathrm{L}^{-1}$ for diuron, DCPMU, DCPU, and

4 tebuconazole $2 \mu \mathrm{g} \mathrm{L}^{-1}$ for procymidone. Minimum detectable concentration was $0.25 \mathrm{mg} \mathrm{L}^{-1}$ 5 for $\mathrm{Br}^{-}$.

\subsection{Soil characterization}

At the end of the monitoring period, the gravimetric soil water content was measured.

Then the soil columns were weighed and dried at $105^{\circ} \mathrm{C}$ for 24 hours before reweighing. For

11 the outdoor soil columns, the mean porosities were $0.37 \pm 0.02 \mathrm{~cm}^{3} \mathrm{~cm}^{-3}$ for the bare soil $(0.41 \pm$ $0.04 \mathrm{~cm}^{3} \mathrm{~cm}^{-3}$ for laboratory columns), $0.46 \pm 0.05 \mathrm{~cm}^{3} \mathrm{~cm}^{-3}$ for the buffer zone soil $(0.37 \pm 0.02$ $\mathrm{cm}^{3} \mathrm{~cm}^{-3}$ for laboratory columns), and $0.28 \pm 0.06 \mathrm{~cm}^{3} \mathrm{~cm}^{-3}$ for the grass covered inter-row soil. The soil columns were then divided into 5 horizontal sections $(0-2.5 \mathrm{~cm} ; 2.5-5 \mathrm{~cm}, 5-10 \mathrm{~cm}$; $10-15 \mathrm{~cm} ; 15-20 \mathrm{~cm}$ ), air-dried, weighed, and sieved to $<2 \mathrm{~mm}$. The $>2 \mathrm{~mm}$ fractions were weighed as the coarse fraction. The $<2 \mathrm{~mm}$ fractions were characterized by determinations of texture (NFX 31-107), pH (NF ISO 10390), and total organic C (NF ISO 10694) at INRAArras, France. The main properties of the two soils studied are presented in Table 2. The surface soils from the buffer zone and the grass covered inter-rows contained more organic carbon (4.0 and 3.9\%, respectively) than the bare vineyard soil (0.8\%) (Table 2).

\subsection{Batch sorption coefficient measurement}

For each treatment (buffer zone, grass covered inter-row and bare soils), the sorption of 
1 and Folicur EW, respectively) was measured using a batch equilibrium method. Each sample

2 consisted of $2 \mathrm{~g}$ dried soil $(0-5 \mathrm{~cm}$ depth) placed in a $50 \mathrm{~mL}$ Teflon centrifuge tube with 10

$3 \mathrm{~mL}$ of $1,2.5,5$ and $10 \mathrm{mg} \mathrm{L}^{-1}$ diuron, procymidone or tebuconazole solution. The tubes were

4 agitated on a rotary shaker for $24 \mathrm{~h}$ at $20^{\circ} \mathrm{C}$ in order to reach steady-state, then centrifuged for $520 \mathrm{~min}$ at $4000 \mathrm{~g}$ (Beckman-Avanti $\mathrm{J}-25$ centrifuge maintained at $20 \pm 1^{\circ} \mathrm{C}$. Blanks were 6 prepared without soil to measure pesticide sorption to the centrifuge tube. The amount of 7 pesticide adsorbed by the sample at equilibrium was determined by the difference between the initial and equilibrium pesticide concentrations in solution corrected by the blank sorption measurement. The experiment was performed in triplicate. Distribution coefficients $\mathrm{K}_{\mathrm{d}}\left(\mathrm{L} \mathrm{kg}^{-}\right.$ ${ }^{1}$ ) for diuron, procymidone and tebuconazole were calculated for each soil sample.

$$
\mathrm{x} / \mathrm{m}=\mathrm{K}_{\mathrm{d}} \mathrm{x} \mathrm{C}_{\mathrm{eq}}
$$

Where $\mathrm{x} / \mathrm{m}$ is the amount of herbicide $\left(\mathrm{mg}\right.$ ) adsorbed per $\mathrm{kg}$ of soil and $\mathrm{C}_{\mathrm{eq}}$ is the diuron equilibrium concentration $\left(\mathrm{mg} \mathrm{L}^{-1}\right)$.

\section{Results and discussion}

\subsection{Sorption isotherms of diuron, tebuconazole and procymidone}

For all three pesticides, the sorption coefficients are higher in the soil from the buffer zone $\left(\mathrm{K}_{\mathrm{d}}=12.0-42.2 \mathrm{~L} \mathrm{~kg}^{-1}\right)$ than in the grass-covered inter-row soil $\left(\mathrm{K}_{\mathrm{d}}=4.9-19.1 \mathrm{~L} \mathrm{~kg}^{-1}\right)$ and the bare soil $\left(\mathrm{K}_{\mathrm{d}}=2.2-10.5 \mathrm{~L} \mathrm{~kg}^{-1}\right)$ (Fig.1, table 3). These results may be explained by the higher organic carbon contents in the $0-5 \mathrm{~cm}$ depth soil of the buffer zone and grass-covered inter-rows $(3.8 \%$ and $2.7 \%$, respectively) than in the same depth of the bare soil $(0.8 \%)$ 
1 buffer zone soils seems to be more reactive $\left(\mathrm{K}_{\mathrm{oc}}\right.$ from 275 to $\left.1314 \mathrm{~L} \mathrm{~kg}^{-1}\right)$ than that of the

2 grass covered soil $\left(\mathrm{K}_{\mathrm{oc}}\right.$ from 183 to $\left.709 \mathrm{~L} \mathrm{~kg}^{-1}\right)$.

In the buffer zone, grass cover and bare soils, tebuconazole (folicur) is adsorbed in

4 greater amounts $\left(\mathrm{K}_{\mathrm{d}}=10.5-42.2 \mathrm{~L} \mathrm{~kg}^{-1}\right)$ than procymidone (sumisclex) $\left(\mathrm{K}_{\mathrm{d}}=4.2-14.1 \mathrm{~L} \mathrm{~kg}^{-1}\right)$

5 and diuron (canyon) $\left(\mathrm{K}_{\mathrm{d}}=2.2-12.0 \mathrm{~L} \mathrm{~kg}^{-1}\right)$. These sorption coefficients are of the same

6 magnitude as those reported in the literature (Table 1; Gonzales-Pradas et al. 2002; Close et

7 al. 2005). In particular, similar diuron sorption values were obtained by Lacas (2005) with

8 bare soil from the $0-20 \mathrm{~cm}$ depth $\left(\mathrm{K}_{\mathrm{d}}=4.6 \mathrm{~L} \mathrm{~kg}^{-1}\right)$ and buffer zone soil from the $0-5 \mathrm{~cm}$ depth

$9 \quad\left(\mathrm{~K}_{\mathrm{d}}=14.2 \mathrm{~L} \mathrm{~kg}^{-1}\right)$.

\subsection{Water infiltration and bromide elution under laboratory conditions}

12

Water flow was relatively homogeneous between the triplicates of each soil treatment, and the eluted water flow rates were quite similar and constant for both the bare $(83.0 \pm 3.0$ $\left.\mathrm{mm} \mathrm{h}^{-1}\right)$ and the buffer zone $\left(80.0 \pm 0.3 \mathrm{~mm} \mathrm{~h}^{-1}\right)$ soils throughout the three flow events. However, the buffer zone flow was slightly lower than the saturation hydraulic conductivity of $125 \mathrm{~mm} \mathrm{~h}^{-1}$ at $15 \mathrm{~cm}$ depth reported by Lacas (2005). After the three water inflow events, we found that bromide was eluted in greater amounts in the leachates of the bare soil $(74.0 \pm$ $1.0 \%)$ than in those of the buffer zone soil (59.9 $\pm 1.2 \%$; Table 4) despite of similar recovered leachate volume. This result could be due to the absorption of bromide by the grass cover vegetation as demonstrated by Xu et al. (2004) with two wetland plants, Typha latifolia and Phragmites australis and more recently by Papiernik et al. (2009). 


\subsection{Pesticides elution under laboratory conditions}

(1)

The quantities of pesticide leached at the end of the three simulations were greater in the bare soil leachates $(8.0 \%$ to $55.1 \%$ of applied) than in those of the buffer zone soil $(6.7 \%$ to $24.3 \%$ ) (Table 4), in correspondence with their sorption coefficients, which were lower in the bare soil $\left(\mathrm{K}_{\mathrm{d}}=2.2-10.5 \mathrm{~L} \mathrm{~kg}^{-1}\right)$ compared to those in the buffer zone soil $\left(\mathrm{K}_{\mathrm{d}}=12.0-42.2 \mathrm{~L}\right.$ $\mathrm{kg}^{-1}$ ) (Table 3). Our results are in contradiction with those of Belden and Coats (2004) that showed that the presence of grass did not modify the total amount of herbicide that leached through soil columns. For both soils, the amounts of pesticides recovered in the leachates varied somewhat between triplicates of a given soil despite having similar pore volumes, coarse fraction contents and bromide recoveries (Table 2, 4).

Diuron metabolites (DCPMU and DCPU) were recovered in greater amounts in the bare soil leachates (7.6 and $1.0 \%$ of the initial amount of parent molecules, respectively) than in those of the buffer zone $(0.2$ and $0.1 \%)$. This result might be explained by the faster degradation of diuron in the bare soil (chemically-weeded) by a microbial population adapted to the herbicide due to repeated agricultural diuron treatments on the vineyard plot as seen by Rouchaud et al. (2000). Similar results were found by Belden and Coats (2004) with atrazine where more deethyl-atrazine was recovered in leachates of non-vegetated soils than the leachates of vegetated soil. Our hypothesis of enhanced biodegradation in the bare soil could not be verified for tebuconazole and procymidone because metabolites were not monitored; nevertheless, Potter et al. (2005) showed that repeated application of tebuconazole increases its dissipation rate in soil.

Of the total amounts of pesticide leached in the three simulations (Table 4), greater amounts of diuron were recovered in the percolates of bare and buffer zone soils $(32.2 \%$ and $14.6 \%$ of the applied amount, respectively) than tebuconazole ( $8.0 \%$ and $6.7 \%$, respectively) 
1 in correspondence with their respective sorption coefficients $\left(\mathrm{K}_{\mathrm{d}}=2.2-12.0 \mathrm{~L} \mathrm{~kg}^{-1}\right.$ and $10.5-$

$\left.2 \quad 42.2 \mathrm{~L} \mathrm{~kg}^{-1}\right)$. However, procymidone was measured in greater amounts in the leachates (24.3

to $55.1 \%$ ) than either diuron or tebuconazole, contrary to what would be expected based on its

4 sorption coefficient $\left(\left(\mathrm{K}_{\mathrm{d}}=4.2-14.1 \mathrm{~L} \mathrm{~kg}^{-1}\right)\right.$ (Tables 3, 5). This may be due to the facilitated transport of procymidone bound to dissolved organic matter as suggested by Gonzales-Pradas et al. (2002).

After the second and third runoff events (14 and 28 days after the first inflow event) when only water was applied to the soils, low to significant amounts of pesticides were released to the soil solution (11.3-50.4\% of the total leached amounts, or, 1.5 to $26.4 \%$ of the applied pesticide). These values are of the same order of magnitude as those reported by Belden and Coats (2004) who recovered from 10 to $20 \%$ of the applied atrazine or metolachlor in soil leachates. The buffer zone soil released less pesticide to the soil solution ( 0.9 to $12 \%$ of the applied amounts) than the bare soil (1.5 to $26.4 \%)$ (Table 5) in agreement with its higher sorption coefficients $\left(\mathrm{K}_{\mathrm{d}}=12.0-42.2 \mathrm{~L} \mathrm{~kg}^{-1}\right.$ relative to $\mathrm{K}_{\mathrm{d}}=2.2-10.5 \mathrm{~L} \mathrm{~kg}^{-1}$ for the bare soil). Additional processes such as long-term non-equilibrium sorption and formation of non-reversible residues may be involved; indeed, Benoit et al. (2000) showed a greater formation of non-extractable residues in the grassed strip soil compared to a cultivated soil. Furthermore, diuron was detected in greater amounts (4.4 to $11.5 \%$ of applied) than tebuconazole ( 0.9 to $1.5 \%$ ) in the leachates, also in agreement with their respective sorption coefficients (Table 3) and with their relatively similar half-life (Table 1). Again, procymidone was released in greater amounts (12.0 to $26.4 \%)$ than either diuron or tebuconazole (Table 5), which may be explained by its very high persistence, particularly in acidic soils (Footprint, 2007-2008), and suspected facilitated transport with dissolved organic matter. 
Water flow was relatively homogeneous between the soil treatment replicates. However,

4 the eluted water flow rates were higher in both the bare $\left(47.6 \pm 19.8 \mathrm{~mm} \mathrm{~h}^{-1}\right)$ and buffer zone

$5 \quad\left(66.4 \pm 3.0 \mathrm{~mm} \mathrm{~h}^{-1}\right)$ soils than the grass-covered inter-row soil $\left(7.7 \pm 3.0 \mathrm{~mm} \mathrm{~h}^{-1}\right)$. The lower

6 flow rate could be due to water ponding on the soil surface of the all grass-covered inter-row

soil columns. Consequently 3 hours after percolation began, bromide was recovered in greater amounts in the leachates of the bare $(55.4 \pm 5.8 \%)$ and the buffer zone $(45.5 \pm 26.6 \%)$ soils than in the leachates of the vegetated soil $(6.6 \pm 7.4 \%)$. This result may be related to greater porosity in the buffer zone $\left(0.46 \mathrm{~cm}^{3} \mathrm{~cm}^{-3}\right)$ and the bare $\left(0.37 \mathrm{~cm}^{3} \mathrm{~cm}^{-3}\right)$ soils relative to that of the tractor compacted grass-covered inter-row soil $\left(0.28 \mathrm{~cm}^{3} \mathrm{~cm}^{-3}\right)$. Then the reduced infiltration through the grass-covered inter-row could be a limitation to potential benefits of this management practice, in particular in case of initially compacted soil. Nevertheless, as with the experiments conducted under laboratory conditions, bromide was eluted in greater amounts in the percolates of the bare soils $(81.2 \pm 19.6 \%)$ and the grass cover soils $(83.3 \pm$ $12.4 \%)$ than in those of the buffer zone soils $(63.4 \pm 3.3 \%)$ at the end of all the three runoff events (Table 6). At the St Joseph experimental site, Boivin et al (2007) estimated a bromide leaching rate of $90 \%$ of the total amount added in the inflow, at the $50 \mathrm{~cm}$ soil depth, which compares well with our results, especially when considering the uncertainty linked to this strip $\left(25 \mathrm{~m}^{2}\right)$. 


\subsection{Pesticides elution under outdoor conditions}

(1)

The amounts of the three pesticides leached through the soils after applying simulated runoff were in the same order of magnitude under both laboratory and outdoor conditions (Table 6). Under outdoor conditions, the pesticides were recovered in greater amounts in percolates of the bare soil (from 12.9 to $45.4 \%$ ) than in those of the buffer zone (from 2.7 to $11.9 \%$ ) and grass-covered inter-row (from 4.4 to $11.0 \%$ ) soils (Table 6). The results obtained for the bare and the buffer zone soils corresponded to the same value than those measured under laboratory conditions which means the outdoor environmental conditions (temperature, rainfall, and solar radiation) did not induce a significant differentiation of the pesticide release after the 28 days of the experiment for each modality. This could be explained by the scarce rainfall measured during the monitoring period, and permitted to compare all the soil cover modalities under laboratory or outdoor conditions. It appeared that leaching of pesticides through grass-covered inter-row soil was similar to that through the buffer zone soil. The difference between the bare soil and the buffer zone and grass-covered inter-row soils might be explained by both the greater amount of bromide eluted and the lower sorption coefficient of the three pesticides on the bare soil relative to the two other soils. Although the amounts of the three pesticides leached through the buffer zone and the grass-covered inter-row soils were relatively similar, more bromide eluted through the grass covered soil ( $83.3 \%$ compared to $63.4 \%$ for the buffer zone) and lower quantities of the pesticides adsorbed to the grass covered soil $\left(\mathrm{K}_{\mathrm{d}}=4.9-19.1 \mathrm{~L} \mathrm{~kg}^{-1}\right)$ than the buffer zone soil $\left(\mathrm{K}_{\mathrm{d}}=12.0-42.2 \mathrm{~L} \mathrm{~kg}^{-1}\right)$. However, one must remember that the water flow rates were far lower (eight times) in the grass-covered inter-row soil columns than the buffer zone soil columns. One hypothesis is that the longer contact times between the pesticides and soil in the grass-covered inter-row columns (due to ponding conditions) favours sorption, as it has been observed for the sorption 
1 of four pesticides on an organic substrate in an experimental flume (Boutron et al. 2009). A

2 lower water flow also decreases the degree of non-equilibrium sorption (Pot et al., 2005). As

3 in the experiment conducted under laboratory conditions, procymidone (from 10.2 to $45.4 \%$ )

4 was eluted in higher amounts than diuron (from 8.9 to 27.8\%) and tebuconazole (from 2.7 to 12.9\%) through the three soils. Again, these results might be explained by the higher sorption coefficients of tebuconazole $\left(\mathrm{K}_{\mathrm{d}}=10.5-42.2 \mathrm{~L} \mathrm{~kg}^{-1}\right)$ relative to those of procymidone $\left(\mathrm{K}_{\mathrm{d}}=\right.$ 4.2-14.1 $\mathrm{L} \mathrm{kg}^{-1}$ ) and diuron $\left(\mathrm{K}_{\mathrm{d}}=2.2-12.0 \mathrm{~L} \mathrm{~kg}^{-1}\right.$ ) (Table 3) and possible facilitated transport of procymidone by dissolved organic matter as previously suggested by Gonzales-Pradas et al. (2002).

As with the experiment conducted under laboratory conditions, significant quantities of the three pesticides were released to the soil solutions after the second and third runoff events (from 23.7 to $69.0 \%$ of the total leached amounts). The buffer zone and grass-covered interrow soils released less pesticide to the soil solution (from 1.9 to $3.8 \%$ and from 3.1 to $5.6 \%$ of the applied amounts, respectively) than the bare soil (7.2 to 15.0\%) (Table 7), in relation with their sorption coefficients $\left(\mathrm{K}_{\mathrm{d}}=12.0-42.2 \mathrm{~L} \mathrm{~kg}^{-1}\right.$ and $\mathrm{K}_{\mathrm{d}}=4.9-19.1 \mathrm{~L} \mathrm{~kg}^{-1}$ for the buffer zone and grass cover soils, respectively, and $\mathrm{K}_{\mathrm{d}}=2.2-10.5 \mathrm{~L} \mathrm{~kg}^{-1}$ for the bare soil) (Table 7). In addition, these results could be explained by a long-term non-equilibrium sorption. Furthermore, the formation of non-extractable residues could be greater in the buffer zone and the grass-covered soils than in the bare soil. As in the laboratory experiment, and probably for the same reasons previously given, procymidone was released in greater amounts (3.8 to $15.0 \%$ ) than tebuconazole (1.9 to $7.6 \%$ ) and diuron (3.4 to $7.2 \%$ ) (Table 7 ).

Boivin et al. (2007) also found that more diuron (34\%) than tebuconazole (31\%) leached through the buffer zone at the St Joseph experimental site. Although their values are far higher than ours ( $8.5 \%$ for diuron and $0.8 \%$ for tebuconazole), the uncertainty associated with 
1 through the buffer strip from the measured water volumes and pesticide concentrations

2 reaching the four lysimeters, which only collected $1 \mathrm{~m}^{2}(4 \%)$ of the buffer surface, and

3 extrapolated the results to the whole surface.

\section{Conclusions}

Results on pesticide transfer through the undisturbed soil columns according to the different soil cover modalities (bare soil or buffer zone) were in good agreement whatever they were obtained under laboratory or outdoor conditions which could be explained by the low rainfall amount during the outdoor experiment; considering all the soil cover modalities (bare soil or buffer zone and grass inter-rows), it systematically appears that more diuron than tebuconazole was recovered in the leachates, in agreement with their sorption coefficients. However, more procymidone than diuron was recovered in the leachates, despite their similar sorption coefficients. This may be due to the facilitated transport of procymidone by dissolved organic matter. All three pesticides used in this study were eluted in lower amounts through the grass-covered soils (buffer zone and inter-rows) than through the bare soil, in relation with their sorption coefficients, which were from 2 to 4 times higher in the grass-cover soils (buffer zone and inter rows) than in the bare soil. Thus it appears that grass-covered soils (buffer zone and inter-rows) reduce the amounts of pesticide leached; consequently, buffer zones decrease the risk of surface water contamination without increasing the risk of groundwater contamination by pesticides. Nevertheless, the reduction of the water infiltration capacity in the wheeled compacted grass-covered inter-row may limit its effectiveness in pesticide surface transfer reduction by increasing runoff. Consequently, it is not enough to establish a grass cover in the inter-row, one also has to check its good infiltration capacity especially avoiding soil compaction by tractors. However, significant quantities of pesticides 
1 were released from the soil after runoff events occurring 2 to 4 weeks after the initial runoff

2 event containing the pesticides and were systematically higher from the bare soil than from 3 the grassed soils.

Comparison with field studies on pesticide transfer through a buffer zone which were conducted in the same area from which the soil columns were collected, suggests that higher

6 pesticide leaching rates occur in the field. However, in the latter, a higher spatial heterogeneity of runoff and subsequent infiltration through the surface of the grassed plot, coupled with the higher runoff water flow rates may explain this difference. Indeed, both phenomena are suspected to lead to a higher participation of macroporous pathways contributing to the total leachate volume, increasing the risk of rapid transport without equilibrium sorption. Consequently, in complement of the undisturbed soil columns study reported here, which permitted to compare the influence of the different soil cover modalities on pesticide transfer with a reasonable experimental effort, further field monitoring is necessary to assess the real infiltration capacity of a buffer zone taking into account the spatial heterogeneity of this parameter onto the plot and the influence of macropore flow on pesticide leaching through the grass cover soil. In addition, the long-term behaviour of pesticides accumulated in the buffer zone should be also monitored.

\section{Acknowledgements}

We thank M. Ducroux and M. Guignier (viticulturists in Villié-Morgon) who so graciously granted us access to their vineyards. The authors would like to thank A. Jacobson (Utah State University, Logan, USA) for her valuable comments on the manuscript. This work was 


\section{References}

Arora, K., Mickelson, S.K., Baker, J.L. 2003. Effectiveness of vegetated buffer strips in reducing pesticide transport in simulated runoff. Transactions of the ASAE 46, 635-644.

Belden, J.B., Coats, J.R. 2004. Effect of grasses on herbicide fate in the soil column: infiltration of runoff, movement, and degradation. Environmental Toxicology and Chemistry 23, 2251-2258.

Benoit, P., Barriuso, E., Vidon, P., Réal B. 2000. Isoproturon movement and dissipation in undisturbed soil cores from a grassed buffer strip. Agronomie 20, 297-307.

Benoit, P., Barriuso, E., Vidon, P., Réal, B. 1999. Isoproturon sorption and degradation in a soil from grassed buffer strip. Journal of Environmental Quality 28, 121-129.

Benoit, P., Souiller, C., Madrigal, I., Pot, V., Réal, B., Coquet, Y., Margoum, C., Laillet, B., Dutertre, A., Gril, J.J., Barriuso, E. 2003. Fonctions environnementales des dispositifs enherbés en vue de la gestion et de la maîtrise des impacts d'origine agricole. Etude et Gestion des Sols 10, 299-312.

Bermudez-Couso, A., Arias-Estevez, M., Novoa-Munoz, J.C., Lopez-Periago, E., SotoGonzales, B., Simal-Gandara, J. 2007. Seasonal distributions of fungicides in soils and sediments of a small river basin partially devoted to vineyards. Water Research 41, $4515-4525$.

Boivin, A., Lacas, J.J., Carluer, N., Margoum, C., Gril, JJ, Gouy, V. 2007. Pesticide leaching potential through the soil of a buffer strip in the river Morcille catchment (Beaujolais). In Environmental fate and ecological effects of pesticides, Del Re AAM., Capri, E., Fragoulis, G., Trevisan, M. (Eds.), XIII Symposium Pesticide Chemistry, Piacenza, Italy, 3-6 September 2007. 
1 Boutron, O., Margoum, C., Chovelon, J.M., Guillemain, C., Gouy, V. Laboratory studies of the adsorption of two pesticides using a batch design and an experimental flume: influence of contact conditions. International Journal of Environmental Analytical Chemistry, in press.

Boyd, P.M., Baker, J.L., Mickelson, S.K., Ahmed, S.I. 2003. Pesticide transport with surface runoff and subsurface drainage through a vegetative filter strip. Transactions of the ASAE 46(3), 675-684.

Close, M.E., Lee, R., Magesan, G.N., Stewart, M.K., Skuse, G., Bekesi, G. 2005. Field study of pesticide leaching in a Himatangi sand (Manawatu) and in a Kiripaka bouldery clay loam (Northland). 1. Results. Australian Journal of Soil Research 43, 457-469.

Delphin, J.E., Chapot, J.Y. 2001. Leaching of atrazine and deethylatrazine under a vegetative filter strip. Agronomie 21, 461-470.

Dillaha, T.A., Reneau, R.B., Mostaghimi, S., Lee, D. 1989. Vegetative filter strips for agricultural nonpoint source pollution control. Transactions of the ASAE 32, 513-519.

European Community Council. 1998. Directive concerning the quality of water intended for human consumption. Official Journal of the European Communities, 98/83 EEC L330, European Union's publisher, Luxembourg, L, 32-54.

FAO, 1998. World reference base for soil resources. ISSS-ISRIC-FAO, FAO, Rome, Italy, World Soil Resources Reports n84, 109 pp.

Footprint 2007-2008. The FOOTPRINT Pesticide Properties Database. Database collated by the University of Hertfordshire as part of the EU-funded FOOTPRINT project (FP6SSP-022704).

Gonzales-Pradas, E., Urena-Amate, M.D, Flores-Cespedes, F., Fernandez-Perez, M., Garratt, J., Wilkins, R. 2002. Leaching of imidacloprid and procymidone in a greenhouse of southeast of Spain. Soil Science Society of America Journal 66, 1821-1828. 
1 IFEN. 2007. Les pesticides dans les eaux. Données 2005. Les dossiers. Nº9, 35 p.

2 Jordan, C.F. 1968. A simple tension-free lysimeter. Soil Science, 105 (2), 1-86.

3 Kloppel, H., Kördel, W., Stein, B. 1997. Herbicide transport by surface runoff and herbicide retention in a filter strip - rainfall and runoff simulation studies. Chemosphere 35, 129141.

Krutz, L.J., Senseman, S.A., Zablotowicz, R.M., Matocha, M.A. 2005. Reducing herbicide runoff from agricultural fields with vegetative filter strips: a review. Weed Science 53, $353-367$.

Krutz, L.J., Senseman, S.A., McInnes, K.J., Hoffmann, D.W., Tierney, D.P. 2004. Adsorption and desorption of metolachlor and metolachlor metabolites in vegetated filter strip and cultivated soil. Journal of Environmental Quality 33, 939-945.

Krutz, L.J., Senseman, S.A., McInnes, K.J., Zuberer, D.A., Tierney, D.P. 2003. Adsorption and desorption of atrazine, desethylatrazine, deisopropylatrazine, and hydroxyatrazine in vegetated filter strip and cultivated soil. Journal of Agricultural and Food Chemistry 51, 7379-7384.

Lacas, J.G. 2005. Processus de dissipation des produits phytosanitaires dans les zones tampons enherbées. Doctoral Thesis Université of Montpellier 2, 307 p.

Lacas, J.G., Voltz, M., Gouy, V., Carluer, N., Gril, JJ. 2005. Using grassed strips to limit pesticide transfer to surface water: a review. Agronomy for Sustainable Development 25, 253-266.

Landry, D., Dousset, S., Andreux, F. 2006. Leaching of oryzalin and diuron through undisturbed vineyard soil columns under outdoor conditions. Chemosphere 62, 1736-1747.

Lennartz, B., Louchart, P., Andrieux, P., Voltz, M. 1997. Diuron and simazine losses to runoff water in Mediterranean vineyards. Journal of Environmental Quality 26, 14931502. 
1 Liaghat, A., Prasher, S.O. 1996. A lysimeter study of grass cover and water table depth effects on pesticides residues in drainage water. Transactions of the ASAE 39, 1731-1738.

Louchart, X., Voltz, M., Andrieux, P., Moussat, R. 2001. Herbicide transport to surface waters at field and watershed scales in a Mediterranean vineyard area. Journal of Environmental Quality 30, 982-991.

Louchart, X., Voltz, M., Coulouma, G., Andrieux, P. 2004. Oryzalin fate and transport in runoff water in Mediterranean vineyards. Chemosphere 57, 921-930.

Madrigal, I., Benoit, P., Barriuso, E., Etiévant, V., Souiller, C., Réal, B., Dutertre, A. 2002. Capacités de stockage et d'épuration des sols de dispositifs enherbés vis-à-vis des produits phytosanitaires. Deuxième partie propriétés de rétention de deux herbicides,

Mersie, W., Seybold, C.A., McNamee, C., Huang, J. 1999. Effectiveness of switchgrass filter l'isoproturon et le diflufénicanil dans différents sols de bandes enherbées. Etude et

Mersie, W., Seybold, C.A., McNamee, C., Lawson, M.A. 2003. Abating endosulfan from runoff using vegetative filter strips: the importance of plant species and flow rate. Agriculture, Ecosystems \& Environment 97, 215-223.

Papiernik, S.K., Koskinen, W.C., Yates, S.R. 2009. Solute transport in eroded and

Patty, L., Réal, B., Gril, J.J. 1997. The use of grassed buffer strips to remove pesticides, nitrate and soluble phosphorus compounds from runoff water. Pesticide Science 49, 243-251. 
1 Pot, V., Simunek, J., Benoit, P., Coquet, Y., Yra, A., Martinez-Cordon MJ. 2005. Impact of rainfall intensity on the transport of two herbicides in undisturbed grassed filter strip soil cores. Journal of Contaminant Hydrology 81, 63-88.

Potter, T.L., Strickland, T.C., Joo, H., Culbreath, A.K. 2005. Accelerated soil dissipation of tebuconazole following multiple applications to peanut. Journal of Environmental Quality 34, 1205-1213.

Rouchaud, J., Neus, O., Bulcke, R., Cools, K., Eelen, H., Dekkers, T. 2000. Soil dissipation of diuron, chlorotoluron, simazine, propyzamide, and diflufenican herbicides after repeated applications in fruit tree orchards. Archives of Environmental Contamination and Toxicology 39, 60-65.

Schmitt, T.J., Dosskey, M.G., Hoagland, K.D. 1999. Filter strip performance and processes for different vegetation, widths, and contaminants. Journal of Environmental Quality 28, 1479-1489.

Seybold, C., Mersie, W., Delorem, D. 2001. Removal and degradation of atrazine and metolachlor by vegetative filter strips on clay loam soil. Communications in Soil Science and Plant Analysis 32, 723-737.

Souiller, C., Coquet, Y., Pot, V., Benoit, P., Réal, B., Margoum, C., Laillet, B., Labat, C., Vachier, P., Dutertre, A. 2002. Capacités de stockage et d'épuration des sols de dispositifs enherbés vis-à-vis des produits phytosanitaires. Première partie : dissipation des produits phytosanitaires à travers un dispositif enherbé; mise en évidence des processus mis en jeu par simulation de ruissellement et infiltrométrie. Etude et Gestion des Sols, 9, 269-285.

Staddon, W.J., Locke, M.A., Zablotowicz, R.M. 2001. Microbiological characteristics of a vegetative buffer strip soil and degradation and sorption of metolachlor. Soil Science Society of America Journal 65, 1136-1142. 
1 VanDijk, PM., Kwadd, F.J.P.M.K., Klapwijk, M. 1996. Retention of water and sediment by grass strips. Hydrological Processes 10, 1069-1080.

3 Vincent, A., Benoit, P., Pot, V., Madrigal., Delgado-Moreno, L., Labat, C. 2007. Impact of different land uses on the mitigation of two herbicides in a silt loam soil: unsaturated soil column displacement studies. European Journal of Soil Science 58, 320-328.

6 Watanabe, H., Grismer, M.E. 2001. Diazinon transport through inter-row vegetative filter strips: micro-ecosystem modeling. Journal of Hydrology 247, 183-199. Science and Technology 38, 5642-5648. 

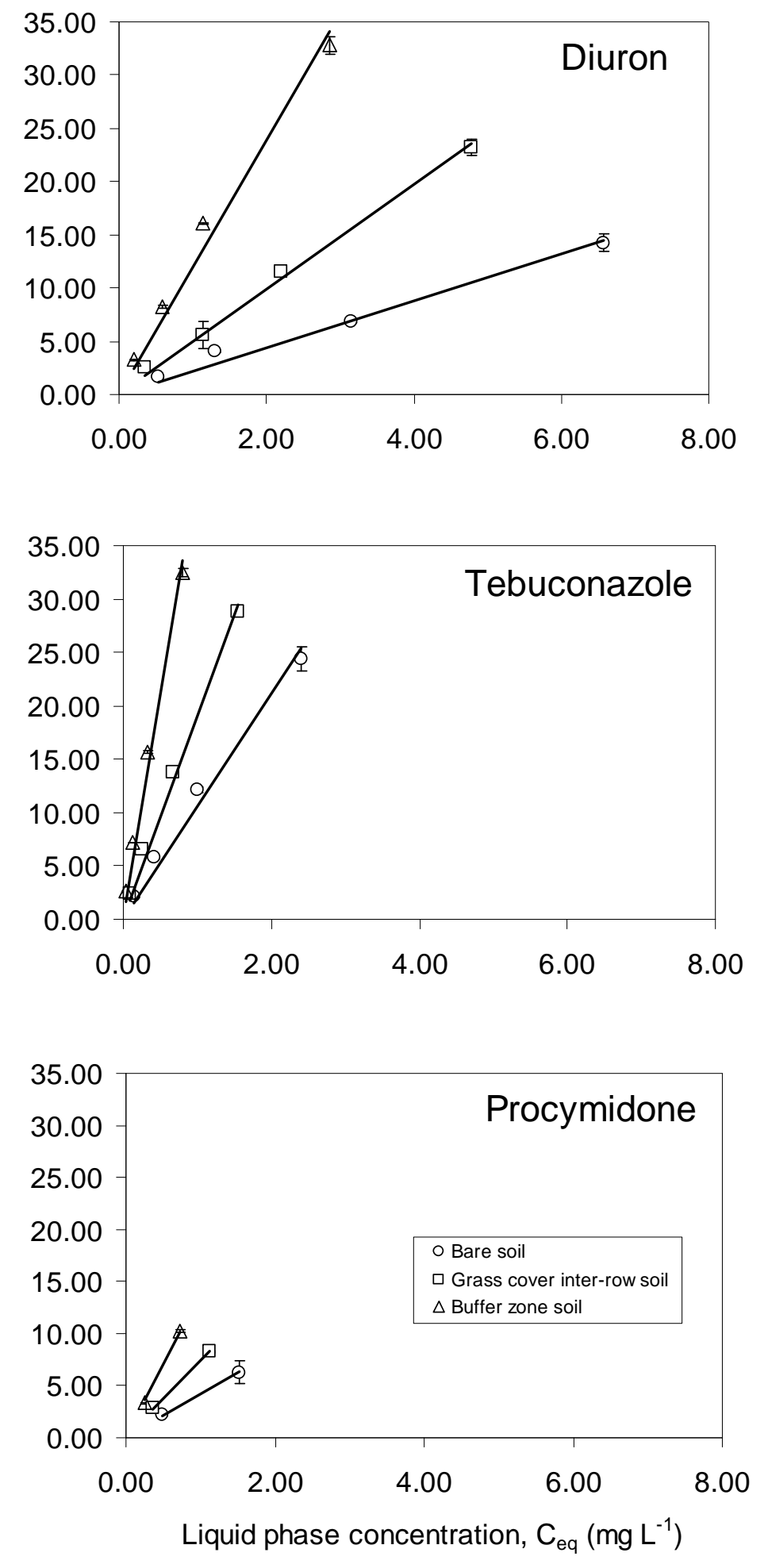

24 Fig. 1. Sorption isotherms for diuron, tebuconazole and procymidone by the bare soil, the 25 grass cover inter-row soil and the buffer zone soil (0-5 cm depth). 
1 Table 1: Main physico-chemical properties of diuron, tebuconazole and procymidone

2 (Footprint, 2007-2008).

3

\begin{tabular}{lccc}
\hline & $\begin{array}{c}\text { Diuron } \\
\text { (phenylurea) }\end{array}$ & $\begin{array}{c}\text { Tebuconazole } \\
\text { (triazole) }\end{array}$ & $\begin{array}{c}\text { Procymidone } \\
\text { (dicarboximide) }\end{array}$ \\
\hline Water solubility $\left(20^{\circ} \mathrm{C}\right)$ & 35.6 & 36 & 2.5 \\
$\left(\mathrm{mg} \mathrm{L}^{-1}\right)$ & & & \\
Vapor pressure $\left(25^{\circ} \mathrm{C}\right)$ & $1.15 \times 10^{-3}$ & $1.3 \times 10^{-3}$ & 0.023 \\
$(\mathrm{mPa})$ & 1067 & 992 & 378 \\
Sorption coefficient $\mathrm{K}_{\mathrm{oc}}$ & $(161-1666)$ & $(803-1249)$ & $(199-1500)$ \\
$\left(\mathrm{L} \mathrm{Kg}{ }^{-1}\right)$ & 75.5 & 62 & 7 \\
Half-life $\left(20^{\circ} \mathrm{C}\right)$ & $(20-231)$ & $(20-610)$ & $(17-2381)$ \\
$($ day $)$ & & & \\
\hline
\end{tabular}

4 
2 Table 2: Main characteristics of the soils (means \pm standard deviation of triplicates).

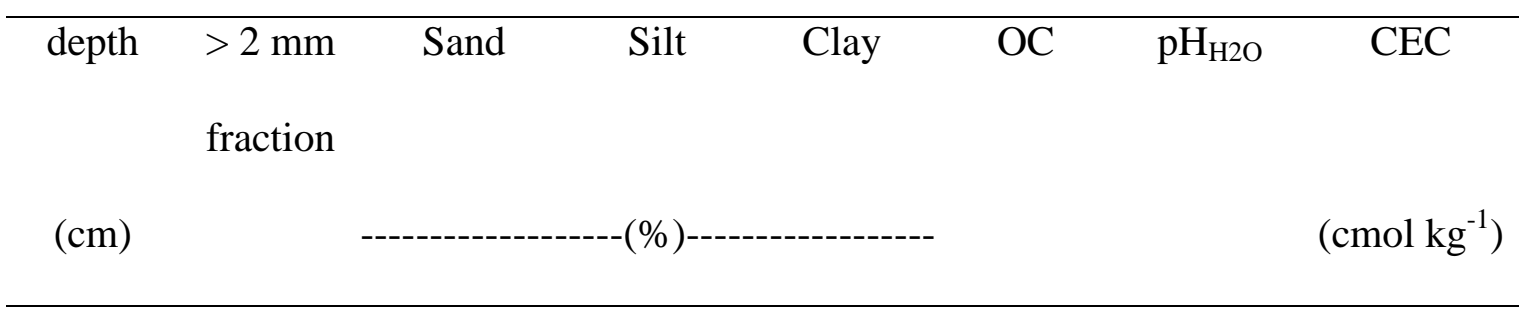

Bare Vineyard soil (or chemically treated) (sand)

$\begin{array}{llllllll}0-2.5 & 4.5 \pm 1.8 & 85.2 \pm 6.6 & 9.5 \pm 4.1 & 5.3 \pm 2.5 & 0.8 \pm 0.2 & 5.3 \pm 0.3 & 4.1 \pm 1.2 \\ 2.5-5 & 4.1 \pm 0.7 & 79.2 \pm 6.9 & 13.2 \pm 4.3 & 7.7 \pm 2.6 & 0.8 \pm 0.2 & 5.0 \pm 0.2 & 5.1 \pm 1.9 \\ 5-10 & 9.0 \pm 1.4 & 75.8 \pm 3.5 & 15.2 \pm 2.1 & 9.0 \pm 1.5 & 0.8 \pm 0.1 & 4.7 \pm 0.4 & 6.2 \pm 0.9 \\ 10-15 & 8.2 \pm 1.4 & 74.5 \pm 2.1 & 15.8 \pm 1.3 & 9.7 \pm 1.0 & 0.7 \pm 0.1 & 4.8 \pm 0.7 & 6.0 \pm 1.4 \\ 15-20 & 4.6 \pm 3.2 & 76.1 \pm 4.4 & 14.6 \pm 2.8 & 9.2 \pm 1.7 & 0.7 \pm 0.2 & 4.6 \pm 0.4 & 6.5 \pm 1.3\end{array}$

Buffer zone (loamy sand)

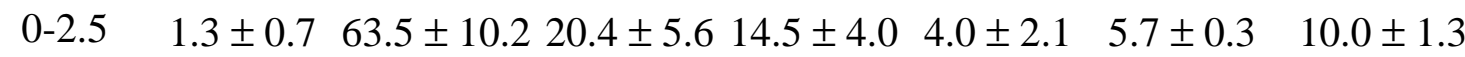

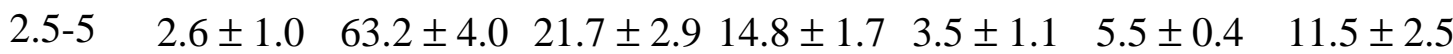

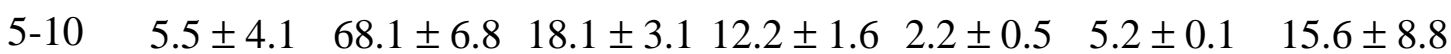

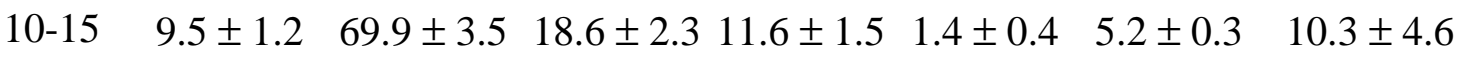

$15-20 \quad 5.3 \pm 4.8 \quad 70.9 \pm 8.8 \quad 17.7 \pm 5.9 \quad 11.4 \pm 2.9 \quad 1.3 \pm 0.3 \quad 5.2 \pm 0.1 \quad 8.8 \pm 1.3$

Grass-covered inter-row soil (loamy sand)
$0-2.5$
$4.0 \pm 1.2$
$78.1 \pm 1.6$
$614.9 \pm 1.97 .0 \pm 1.3$
$3.9 \pm 0.4 \quad 5.7 \pm 0.3$
$8.3 \pm 1.5$
$2.5-$
$7.1 \pm 1.0$
$78.3 \pm 1.3$
$314.5 \pm 0.97 .2 \pm 0.5$
$1.5 \pm 0.4 \quad 5.7 \pm 0.2$
$5.3 \pm 0.2$
5-10
$18.8 \pm 2.3 \quad 74.9 \pm 2.8 \quad 17.0 \pm 1.8 \quad 8.2 \pm 1.1$
$0.9 \pm 0.1$
$5.9 \pm 0.1$
$4.5 \pm 0.8$
$10-15$
$14.6 \pm 7.4 \quad 71.4 \pm 0.6 \quad 17.5 \pm 1.6 \quad 11.1 \pm 0.9 \quad 1.0 \pm 0.8 \quad 5.6 \pm 0.3$
$5.1 \pm 2.7$
$15-2$
$14.2 \pm 4.971 .8 \pm 2.1$
$18.2 \pm 1.69 .9 \pm 0.7$
$0.6 \pm 0.1 \quad 5.8 \pm 0.1$
$3.7 \pm 0.7$ 
2 Table 3: Sorption coefficients $\left(\mathrm{K}_{\mathrm{d}}\right.$ and $\left.\mathrm{K}_{\mathrm{oc}}\right)$ for diuron, tebuconazole and procymidone on the

3 bare soil (B), the buffer zone soil (BZ) and the grass cover inter-row soil (GC) $(0-5 \mathrm{~cm}$

4 depth).

5

6

\begin{tabular}{|c|c|c|c|c|}
\hline \multirow[b]{2}{*}{ Pesticide } & \multirow[b]{2}{*}{ soil } & \multicolumn{2}{|l|}{$\mathbf{K}_{\mathbf{d}}$} & \multirow{2}{*}{$\begin{array}{c}\mathbf{K}_{\mathrm{oc}}{ }^{*} \\
\left(\mathrm{~L} \mathrm{~kg}^{-1}\right)\end{array}$} \\
\hline & & $\left(\mathrm{L} \mathrm{kg}^{-1}\right)$ & $\mathbf{r}^{2}$ & \\
\hline \multirow[t]{3}{*}{ Diuron } & B & 2.20 & 0.982 & 275 \\
\hline & $\mathrm{BZ}$ & 12.0 & 0.979 & 319 \\
\hline & $\mathrm{GC}$ & 4.9 & 0.995 & 183 \\
\hline \multirow[t]{3}{*}{ Tebuconazole } & B & 10.5 & 0.979 & 1314 \\
\hline & $\mathrm{BZ}$ & 42.2 & 0.983 & 1126 \\
\hline & $\mathrm{GC}$ & 19.1 & 0.989 & 709 \\
\hline \multirow[t]{3}{*}{ Procymidone } & B & 4.2 & 0.996 & 519 \\
\hline & $\mathrm{BZ}$ & 14.1 & 0.995 & 375 \\
\hline & $\mathrm{GC}$ & 7.4 & 0.999 & 274 \\
\hline
\end{tabular}

8

9 
2 Table 4: Recovery percentages of initial amounts of bromide, diuron, DCPMU, DCPU,

3 tebuconazole and procymidone summed over the three water inflow events under laboratory

4 conditions for the bare soil $\left(\mathrm{B}_{\mathrm{L}}\right)$ and the buffer zone $\left(\mathrm{BZ}_{\mathrm{L}}\right)$.

5

\begin{tabular}{|c|c|c|c|c|c|c|c|}
\hline & Eluted water & Bromide & Diuron & DCPMU & DCPU & Tebuconazo & Procymidone \\
\hline & volume (L) & $(\%)$ & $(\%)$ & $(\%)$ & $(\%)$ & $(\%)$ & $(\%)$ \\
\hline $\mathrm{B}_{\mathrm{L} 1}$ & 9.7 & 73.1 & 31.5 & 8.9 & 0.1 & 3.9 & 90.1 \\
\hline $\mathrm{B}_{\mathrm{L} 2}$ & 9.6 & 75.1 & 22.7 & 7.0 & 0.1 & 1.3 & 24.3 \\
\hline $\mathrm{B}_{\mathrm{L} 3}$ & 9.4 & 73.9 & 42.5 & 7.1 & 2.9 & 18.7 & 50.8 \\
\hline Mean \pm SD & $9.6 \pm 0.2$ & $74.0 \pm 1.0$ & $32.2 \pm 9.9$ & $7.6 \pm 1.1$ & $1.0 \pm 1.6$ & $8.0 \pm 9.4$ & $55.1 \pm 33.1$ \\
\hline $\mathrm{BZ}_{\mathrm{L} 1}$ & 10.2 & 60.7 & 12.2 & 0.2 & 0.1 & 4.6 & 18.2 \\
\hline $\mathrm{BZ}_{\mathrm{L} 2}$ & 10.3 & 58.5 & 10.3 & 0.1 & 0.0 & 3.7 & 17.5 \\
\hline $\mathrm{BZ}_{\mathrm{L} 3}$ & 10.2 & 60.5 & 21.5 & 0.2 & 0.2 & 11.9 & 37.2 \\
\hline Mean \pm SD & $10.2 \pm 0.1$ & $59.9 \pm 1.2$ & $14.6 \pm 6.0$ & $0.2 \pm 0.1$ & $0.1 \pm 0.1$ & $6.7 \pm 4.5$ & $24.3 \pm 11.1$ \\
\hline
\end{tabular}

7

8

9

10

11 
1 Table 5: Recovery percentages of initial amounts bromide, diuron, DCPMU, DCPU,

2 tebuconazole and procymidone for the $2^{\text {nd }}$ and 3 rd water inflow events (only) under

3 laboratory conditions for the bare soil $\left(\mathrm{B}_{\mathrm{L}}\right)$ and the buffer zone $\left(\mathrm{BZ}_{\mathrm{L}}\right)$.

4

\begin{tabular}{|c|c|c|c|c|c|c|c|}
\hline & $\begin{array}{c}\text { Eluted } \\
\text { water } \\
\text { volume (L) }\end{array}$ & $\begin{array}{c}\text { Bromide } \\
(\%)\end{array}$ & $\begin{array}{l}\text { Diuron } \\
(\%)\end{array}$ & $\begin{array}{c}\text { DCPMU } \\
(\%)\end{array}$ & $\begin{array}{l}\text { DCPU } \\
(\%)\end{array}$ & $\begin{array}{c}\text { Tebuconazol } \\
(\%)\end{array}$ & $\begin{array}{l}\text { Procymidone } \\
\qquad(\%)\end{array}$ \\
\hline $\mathrm{B}_{\mathrm{L} 1}$ & 6.6 & 7.0 & 11.9 & 5.4 & 0.1 & 0.7 & 51.4 \\
\hline $\mathrm{B}_{\mathrm{L} 2}$ & 6.5 & 8.5 & 12.9 & 4.6 & 0.1 & 0.6 & 11.1 \\
\hline $\mathrm{B}_{\mathrm{L} 3}$ & 6.3 & 2.1 & 9.8 & 4.8 & 2.9 & 3.1 & 16.7 \\
\hline Mean \pm SD & $6.5 \pm 0.1$ & $5.9 \pm 3.4$ & $11.5 \pm 1.6$ & $4.9 \pm 0.4$ & $1.0 \pm 1.6$ & $1.5 \pm 1.4$ & $26.4 \pm 21.8$ \\
\hline $\mathrm{BZ}_{\mathrm{L} 1}$ & 6.8 & 0.5 & 4.0 & 0.2 & 0.1 & 0.2 & 9.2 \\
\hline $\mathrm{BZ}_{\mathrm{L} 2}$ & 6.8 & 3.6 & 3.2 & 0.1 & 0.0 & 0.5 & 9.4 \\
\hline $\mathrm{BZ}_{\mathrm{L} 3}$ & 6.8 & 2.0 & 5.9 & 0.2 & 0.2 & 1.9 & 17.5 \\
\hline Mean $\pm S D$ & $6.8 \pm 0.0$ & $2.0 \pm 1.6$ & $4.4 \pm 1.4$ & $0.2 \pm 0.1$ & $0.1 \pm 0.1$ & $0.9 \pm 0.9$ & $12.0 \pm 4.7$ \\
\hline
\end{tabular}


1 Table 6: Recovery percentages of initial applied amounts bromide, diuron, tebuconazole and

2 procymidone summed over the three water inflows events under outdoor conditions for the

3 bare soil $\left(\mathrm{B}_{\mathrm{O}}\right)$, the buffer zone $(\mathrm{BZ})$ and the grassed-cover soil $\left(\mathrm{GC}_{\mathrm{O}}\right)$.

4

\begin{tabular}{|c|c|c|c|c|c|}
\hline & Eluted water & Bromide & Diuron & Tebuconazol & Procymidone \\
\hline & volume (L) & $(\%)$ & $(\%)$ & $(\%)$ & $(\%)$ \\
\hline $\mathrm{B}_{\mathrm{O} 1}$ & 9.4 & 98.1 & 17.1 & 7.4 & 31.4 \\
\hline $\mathrm{B}_{\mathrm{O} 2}$ & 10.2 & 99.7 & 45.9 & 21.6 & 71.9 \\
\hline $\mathrm{B}_{\mathrm{O} 3} *$ & 9.2 & 54.1 & 20.3 & 6.5 & 31.9 \\
\hline $\mathrm{B}_{\mathrm{O} 4}$ & 9.2 & 89.7 & 17.0 & 7.8 & 32.3 \\
\hline Mean \pm SD & $9.5 \pm 0.5$ & $81.2 \pm 19.6$ & $27.8 \pm 12.9$ & $12.9 \pm 6.8$ & $45.4 \pm 18.7$ \\
\hline $\mathrm{BZ}_{\mathrm{O} 1}$ & 9.6 & 62.6 & 11.1 & 4.6 & 18.3 \\
\hline $\mathrm{BZ}_{\mathrm{O} 2}$ & 8.9 & 67.8 & 21.4 & 0.0 & 0.03 \\
\hline $\mathrm{BZ}_{\mathrm{O} 3}$ & 9.6 & 59.8 & 3.2 & 3.6 & 12.3 \\
\hline Mean \pm SD & $9.4 \pm 0.4$ & $63.4 \pm 3.3$ & $11.9 \pm 7.5$ & $2.7 \pm 2.0$ & $10.2 \pm 7.6$ \\
\hline $\mathrm{GC}_{\mathrm{O} 1} *$ & 7.6 & 66.0 & 3.7 & 1.6 & 8.5 \\
\hline $\mathrm{GC}_{\mathrm{O} 2} *$ & 6.3 & 90.1 & 5.9 & 3.0 & 9.8 \\
\hline $\mathrm{GC}_{\mathrm{O} 3} *$ & 8.6 & 93.9 & 17.0 & 8.6 & 14.6 \\
\hline Mean \pm SD & $7.5 \pm 1.1$ & $83.3 \pm 12.4$ & $8.9 \pm 5.8$ & $4.4 \pm 3.0$ & $11.0 \pm 2.6$ \\
\hline
\end{tabular}


2 Table 7: Recovery percentages of initial applied amounts bromide, diuron, tebuconazole and

3 procymidone following the $2^{\text {nd }}$ and $3^{\text {rd }}$ water inflows (only) under outdoor conditions.

4

\begin{tabular}{|c|c|c|c|c|c|}
\hline & Eluted water & Bromide & Diuron & Tebuconazo & rocymidone \\
\hline & volume (L) & $(\%)$ & $(\%)$ & $(\%)$ & $(\%)$ \\
\hline $\mathrm{B}_{\mathrm{O} 1}$ & 6.2 & 40.8 & 8.9 & 6.5 & 18.5 \\
\hline $\mathrm{B}_{\mathrm{O} 2}$ & 6.7 & 34.0 & 6.7 & 13.6 & 11.5 \\
\hline $\mathrm{B}_{\mathrm{O} 3} *$ & 6.1 & 11.9 & 8.1 & 4.9 & 18.1 \\
\hline $\mathrm{B}_{\mathrm{O} 4}$ & 5.7 & 1.8 & 4.9 & 5.4 & 11.9 \\
\hline Mean \pm SD & $6.2 \pm 0.4$ & $22.1 \pm 18.3$ & $7.2 \pm 1.8$ & $7.6 \pm 4.1$ & $15.0 \pm 3.8$ \\
\hline $\mathrm{BZ}_{\mathrm{O} 1}$ & 5.7 & 0.6 & 2.0 & 2.8 & 5.4 \\
\hline $\mathrm{BZ}_{\mathrm{O} 2}$ & 5.4 & 5.9 & 6.6 & 0.00 & 0.01 \\
\hline $\mathrm{BZ}_{\mathrm{O} 3}$ & 6.1 & 0.0 & 1.5 & 2.91 & 5.9 \\
\hline Mean \pm SD & $5.7 \pm 0.4$ & $2.2 \pm 3.3$ & $3.4 \pm 2.8$ & $1.9 \pm 1.7$ & $3.8 \pm 3.3$ \\
\hline $\mathrm{GC}_{\mathrm{O} 1} *$ & 4.5 & 34.8 & 2.7 & 1.5 & 5.4 \\
\hline $\mathrm{GC}_{\mathrm{O} 2} *$ & 3.4 & 36.7 & 3.7 & 2.3 & 5.6 \\
\hline $\mathrm{GC}_{\mathrm{O} 3} *$ & 5.1 & 5.6 & 4.0 & 4.7 & 5.9 \\
\hline Mean \pm SD & $4.3 \pm 0.8$ & $25.7 \pm 17.4$ & $3.5 \pm 0.7$ & $3.1 \pm 1.4$ & $5.6 \pm 0.3$ \\
\hline \multicolumn{6}{|c|}{ Water ponding on the soil surface } \\
\hline
\end{tabular}

